\title{
The Influence of Knowledge to Handwashing Behavior in The Prevention Of Covid 19
}

\author{
Nana Novariana, Nur Sefa Arief \\ Hermawan, Satria Nandar \\ Baharza \\ Public Health Departement, Health \\ Faculty, University of Mitra \\ Indonesia \\ Email: \\ nana@umitra.ac.id \\ sefa@umitra.ac.id
}

Received: October 13, 2020

Accepted: November 13, 2020

Published : November 30, 2020

\section{ABSTRACT}

Covid-19 (Corona Virus Disease 2019) is a group of viruses that can cause diseases in both animals and humans. Some types of Covid-19 are known to cause infections of the respiratory tract in humans ranging from cough, flu, to more serious such as Middle East Respitory syndrome (MERS) and Severe acute respitory syndrome (SARS). It was detected from the first time in December 2019 in Wuhan, Hubei Province, China. According to the data from Lampung Health Ministry, as of 30 May 2020, Lampung had recorded as many as 20 suspected patients, 8 persons died and 2 probable patients and 131 confirmed patients. One of the ways to prevent the spread of Covid-19 is by washing hands by using soap. The purpose of this research is to determine whether the extent of the knowledge may influence the behavior of handwashing by using soap to prevention of Covid-19.

The research was conducted by using analytical surveys with cross sectional research design. The population is a community in the work area of Publich Health Center in Panjang, consisting of 1197 families. The samples taken were 307 families by using simple random sampling.

Based on the results of the Chi Squre obtained, the results of knowledge of the hand washing behavior of soap-wearing in the prevention of Covid-19 has showed significant results $(\mathrm{p}=0.000$ $\mathrm{OR}=4.11$ ).

Conclusio obtained from the study shows the result that there is a significant relationship between the knowledge and the behavior of handwashing by using soap to the spread of disease Covid-19. Namely, with the low awareness of people to wash hands with soap before eating or drinking activities and others, it causes the incidence of high occurrence of Covid-19 disease in Bandar Lampung especially in the area of Publich Health Center in Panjang district.

Keywords: Covid-19, knowledge, behavior

Copyright @ 2020 IIK STRADA Indonesia

All right reserved.

This is an open-acces article distributed under the terms of the Creative Commons AttributionShareAlike 4.0 International License. 


\section{INTRODUCTION}

The Covid-19 outbreak (Corona virus disease 2019) has become a concern in the world. Currently, 213 countries have confirmed Covid-19. Covid-19 cases alone have now reached 2,810,325 cases with a death rate of 193,825 worldwide as of April 2020. Meanwhile, for Covid-19 cases in Southeast Asia, there were 44,592 confirmed cases (WHO, 2020).

In Indonesia, Covid-19 case was first discovered in March $2^{\text {nd }} 2020$ with two confirmed data cases. The number of Covid-19 cases in Indonesia continued to increase ever since, starting from April 2020, there were 8,882 confirmed cases with a record of 7,032 people under treatment, while the death rate was 743 people, and those who were declared cured of Covid-19 were as many as 1,107 people (Ministry of Health, 2020).

In implementing Covid-19 prevention efforts, to reduce infection or to limit the spread of Covid-19, several simple precautions are taken, such as regularly and thoroughly cleaning hands with alcohol-based rubbing or washing with soap and water. Because washing your hands with soap and water or using alcohol-based hand rub kills viruses that may be on your hands. In addition, it is advisable to avoid touching the eyes, nose and mouth because hands touch many surfaces and can transfer the virus to the eyes, nose or mouth. From there, the virus may infect human and cause the sickness (Ministry of Health, 2020).

Washing hands by using soap can prevent various diseases. Because the hands themselves are the main carrier of germs, and the practice of washing hands by using soap can prevent 1 million deaths. It turns out that washing hands with soap has been proven to be able to prevent human transmission of the corona deases-19 virus (covid-19) which has recently become a pandemic in various countries. In addition, the Ministry of Home Affairs (2020) also states that $70 \%-80 \%$ of Indonesians can be contracted by Covid-19 through their hands which touch their eyes, nose and mouth before washing their hands by using soap.

Thererefore, the problem to be answered in this research is meant to observe the relationship between people's knowledge and their behavior in handwashing by using soap to prevent the spread of Covid 19.

\section{MATERIALS AND METHODS}

The research design used in this study is Cross Sectional While the type of the research in this study is analytical. Because the study is meant to find a relationship between one variable and another and analysis of the data is carried out (Sujarweni, V Wiratna, 2015).

The research was conducted on $1^{\text {st }}$ May $-2^{\text {nd }}$ June 2020 in the working area of Public Health Center located in Panjang district, Lampung. This study has two variables, namely the independent variable is the level of knowledge about washing hands with soap while the dependent variable is the behavior of washing hands by using soap in the prevention of Covid-19.

The population in this study was all households in the work area of Panjang Public Health Center, covering up to 1197 families. The research sample was 307 families, the samples were taken using the simple random sampling technique.

The data collection technique was done by distributing the questionnaire directly to the respondents, then the respondent would answer the statement in the questionnaire that had been prepared by the researcher. After the questionnaire had been answered, the questionnaire is collected to be analyzed. The data collected in this study were analyzed by using univariate and bivariate.

\section{RESULTS}

Table 1. Distribution of Frequency of Respondents' Knowledge on Handwashing in the working area of Panjang Public Health Center in 2020

\begin{tabular}{cccc}
\hline No & Knowledge & Frequenci & $\begin{array}{c}\text { Percentage } \\
(\mathbf{\%})\end{array}$ \\
\hline 1 & Not Good & 101 & 32,8 \\
\hline 2 & Good & 206 & 67,2 \\
\hline & Amount & 307 & 100 \\
\hline
\end{tabular}


Source : (data is collected and analyzed in 2020)

Based on table 1 of the knowledge variable, it can be seen that 307 respondents mostly had good knowledge, namely $206(67.2 \%)$ while the other 101 (32.8\%) respondents were classified as having bad knowledge.

Based on table 2, it is known that of the 307 respondents, 97 (31.6\%) respondents, who wash their hands with soap is categorized as not good, while the number of respondents who had applied the good behavior in washing their hands were 210 (68.4\%). respondents.

Table 2. Distribution of Frequency of Handwashing by using soap behavior in the working area of Panjang Public Health Center in 2020

\begin{tabular}{cccc}
\hline No & $\begin{array}{c}\text { Handwash } \\
\text { ing }\end{array}$ & Frequenci & $\begin{array}{c}\text { Percentage } \\
(\mathbf{\%})\end{array}$ \\
\hline 1 & Not good & 97 & 31,6 \\
\hline 2 & Good & 210 & 68,4 \\
\hline & Amount & 307 & 100 \\
\hline
\end{tabular}

Source : (data is collected and analyzed in 2020)

Table 3.

Distribution of Frequency of The Relationship between Knowledge with Handwashing by using soap behavior in the working area of Panjang Public Health Center in 2020

\begin{tabular}{ccccccccc}
\hline $\begin{array}{c}\text { Knowledge } \\
\text { on }\end{array}$ & \multicolumn{2}{c}{ Handwashing Behavior } & \multicolumn{2}{c}{ Amount } & P Value & \multirow{2}{*}{ OR (95\% } \\
Handwashing & N & \% & Not Good & \% & N & \% & & \\
\hline Good & 156 & 50,8 & 50 & 16,4 & 206 & 67,2 & & \\
Not Good & 54 & 17,6 & 47 & 15,2 & 101 & 32,8 & 0,000 & $1,836-9,204$ \\
Amount & 210 & 68,4 & 97 & 31,6 & 307 & 100 & & \\
\hline
\end{tabular}

Source : (data is collected and analyzed in 2020)

Based on table 3, it can be seen that from 307 respondents, 50 respondents (16.4\%) who have knowledge of handwashing by using soap had bad behavior in washing hands. While 47 respondents $(15.2 \%)$ respondents who did not have good knowledge about handwashing by using soap did not have good behavior when washing hands by using soap. From the statistical test, results obtained were $\mathrm{p} 0.05$, namely $\mathrm{p}=0.000$, which means that there is a significant relationship between knowledge and the behavior of washing hands with soap. In other words, the behavior of washing hands by using soap is influenced by knowledge.

From the analysis, it is obtained that the results of the OR $=4.111$ (95\% CI: 1,836-9,204). From this result, it can be interpreted that respondents with bad knowledge have a chance of 4.111 times to have bad hand washing behavior compared to respondents who have good knowledge of hand washing by using soap.

\section{DISCUSSION}

Based on the results of univariate analysis, it is known that most of the 307 respondents had good knowledge, namely 206 (67.2\%) and 101 (32.8\%) of the respondents had bad knowledge. And it is known from 307 respondents that the behavior of washing hands with soap is not good, 97 (31.6\%) of respondents, while the good behavior is $210(68.4 \%)$ of respondents. $<0.05$, namely $\mathrm{p}=0.000$, which means that there is a significant relationship between knowledge and the behavior of washing hands with soap. In other words, the behavior of washing hands with soap is influenced by knowledge. The results of the analysis obtained the value of OR $=4.111(95 \%$ CI: $1,836-9,204)$ so it 
can be interpreted that respondents with poor knowledge have a chance of 4.111 times to have bad hand washing behavior in compare it with respondents who have good knowledge of washing hands with soap.

Based on the results of the bivariate analysis, it is known that from 307 respondents there are 50 respondents $(16.4 \%)$ with knowledge of washing hands with bad soap who have good behavior in washing hands, while respondents with knowledge of washing hands with good soap have good behavior. well there were 47 respondents (15.2\%).

From the statistical analysis, it is obtained that $p<0.05$, namely $p=0.000$, which means that there is a significant relationship between knowledge and the behavior of washing hands with soap. In other words, the behavior of washing hands with soap is influenced by knowledge. The results of the analysis obtained the value of OR $=4.111(95 \%$ CI: $1,836-9,204)$ so it can be interpreted that respondents with bad knowledge have a chance of 4,111 times to have bad hand washing behavior. compare it with respondents who have good knowledge of washing hands with soap.

According to Notoatmodjo (2018), knowledge is the result of knowing and occurs after people sense a certain object. Sensing occurs through the five human senses, namely through sight, hearing, smell, taste, and touch. Most of human knowledge is obtained through sight and hearing. Knowledge is the result of human knowledge of a certain object or material that has previously been studied, knowledge can be realized when understanding is done by means of perception either through the senses or through reason and mind.

It is better if the Bandar Lampung City Health Office can encourage further about how to wash your hands with soap properly by working with Panjang Public Health Center. It is hoped that the Public Health Center will provide information to the public about washing hands with soap with presentations, public lectures, simulations, etc. Meanwhile, the media that can be used are posters, leaflets, brochures, magazines, newspapers, flipcharts, stickers, and pamphlets.

\section{CONCLUSION}

Based on the research results, it can be concluded that:

a. Respondents who are classified to have a good knowledge were 206 respondents $(67.2 \%)$ and 110 respondents (32.8\%) were still categorized as not good.

b. Respondents with good hand washing behavior by using soap were 201 (68.4\%) respondents, while those who were not good were 97 (31.6\%) respondents.

c. There is a significant relationship between knowledge $(\mathrm{p}=0.000)$ and the behavior of washing hands by using soap in the Panjang Public Health Center, Lampung work area in 2020.

\section{REFERENCES}

Baharuddin dan Rumpa, F.A, (2020). 2019-nCOV Jangan takut virus corona. Yogyakarta: Rapha Publishing.

Covid-19.go.id, (2020). Tanya-Jawab Covid-19. Jakarta.

Bandar Lampung Health Ministry, (2020). Data Covid-19. Lampung.

RI Health Ministry, (2009). Panduan Penyelenggaraan Hari Cuci Tangan Pakai Sabun Sedunia, Jakarta.

RI Health Ministry RI, (2020). Covid-monitoring. Jakarta.

Ministry of Home Affairs, (2020). Data Covid-19. Jakarta.

Kepmenkes RI no. 1429 Tahun 2006. (2006). KEPMENKES_1429_2006.pdf.

RI Health Ministry. (2014). Perilaku Cuci Tangan Pakai Sabun. In Pusdatin Kemenkes RI (p. 3).

Notoatmodjo, (2018). Metodelogi Penelitian Kesehatan, Cetakan ketiga. Jakarta: Rineka Cipta.

Notoatmodjo, (2018). Promosi Kesehatan Dan Perilaku Kesehatan. Jakarta: Rineka Cipta.

Susilo, A., Rumende, C. M., Pitoyo, C. W., Santoso, W. D., Yulianti, M., Sinto, R., Singh, G., et al. (2020). Coronavirus Disease 2019: Tinjauan Literatur Terkini Coronavirus Disease 2019: Review of Current Literatures. Jurnal Penyakit Dalam Indonesia, 7(1), 45-67.

Waluyo, B. H. (2018). WASHinSchool-Guideline for headmasters and teachers.pdf (p. 60).

World Health Organisation (WHO), (2020). CoronaVirus (Covid-19). New York.

World Health Organisation (WHO), (2020). Cuci Tangan Pakai Sabun (CTPS). New York: Perserikatan Bangsa-Bangsa (PBB). 